\title{
'Carmen', a Yellow Canary Melon Breeding Line Resistant to Podosphaera xanthii, Aphis gossypii, and Cucurbit Yellow Stunting Disorder Virus
}

\author{
Francisco Javier Palomares-Rius \\ Enza Zaden Research Mexico, Culiacán, Sinaloa, México
}

\begin{abstract}
Ana Garcés-Claver
Centro de Investigación y Tecnología Agroalimentaria de Aragón, Unidad de Hortofruticultura, Instituto Agroalimentario de Aragón -IA2 (CITA-Universidad de Zaragoza), Zaragoza 50059, Spain
\end{abstract}

\begin{abstract}
María Belén Picó and Cristina Esteras
Instituto Universitario de Conservación y Mejora de la Agrodiversidad Valenciana (COMAV), Universitat Politècnica de València (UPV), Camino de Vera, Valencia 46021, Spain
\end{abstract}

Fernando Juan Yuste-Lisbona

Centro de Investigación en Biotecnología Agroalimentaria (BITAL), Universidad de Almería, Carretera de Sacramento s/n, Almería 04120, Spain

\section{María Luisa Gómez-Guillamón ${ }^{1}$ \\ Plant Breeding and Biotechnology Department, IHSM-La Mayora, UMA- CSIC, Algarrobo 29750, Málaga, Spain}

Additional index words. resistance, Vat gene, powdery mildew, introgression, yellowing virus, fruit quality

Melon (Cucumis melo L., $2 n=2 x=24$ ) is a valuable cash crop grown in temperate and tropical regions worldwide. Currently, the main factor limiting melon crops is the large number of diseases that reduce both yield and crop quality. The limited success of chemicals and the increasing concern about pesticide use have given rise to a renewed interest in genetic disease resistance, which has become a major objective of breeding programs.

Among the diseases affecting melon crops, powdery mildew incited by Podosphaera xanthii (Castagne) U. Braun \& N. Shishkoff (Shishkoff, 2000) and the yellowing incited by Cucurbit yellow stunting disorder virus (CYSDV) and the incidence of

\footnotetext{
Received for publication 19 Mar. 2018. Accepted for publication 3 Apr. 2018.

This research was supported by the Spanish Ministry of Economy and Competitivity co-funded with FEDER (AGL-2008-05687-C02-1, AGL 2011-29516-C02-02, AGL2014-53398-C02-1-R and AGL2014-53398-C2-2-R) and by Generalitat Valenciana through Prometeo Excellence Program (PROMETEO/2017/078).

We thank Emilio Sarria-Villada and Anabel López-Sesé for their scientific support and Rocío Camero, Luis Rodríguez, Carmen Cotilla and Inmaculada Díaz for field and lab assistance. ${ }^{1}$ Corresponding author. E-mail: guillamon@, eelm.csic.es.
}

the cotton-melon aphid, Aphis gossypii are three of the main problems in many areas of the world. Powdery mildew is always present all year round irrespective of the growing system (Sitterly, 1978). Our group reported resistance to races 1,2 , and 5 in the accession TGR-1551 from Zimbabwe, conferred by two independent genes, one dominant and one recessive (Yuste-Lisbona et al., 2009). A major quantitative trait locus (QTL) for resistance to these races on linkage group (LG) $5(P m-R)$ has been identified. The recessive resistance gene derived from TGR-1551 was later mapped on the LG12 (Beraldo et al., 2012) and several SNPs, polymorphic between TGR-1551 and 'Bola de oro', mapped in this candidate region (Esteras et al., 2013).

Cucurbit yellow stunting disorder virus is a Bemisia tabaci-transmitted virus, member of the genus Crinivirus of the family Closteroviridae (Wisler et al., 1998). So far, the main strategy to limit the incidence of virusinfected plants has been the application of insecticides to reduce vector populations combined with integrated pest management cultural practices. There are currently two independent sources of resistance to CYSDV in melon germplasm, the African accession TGR-1551 (López-Sesé and GómezGuillamón, 2000) and the accession PI 313970 from India (McCreight and Wintermantel, 2008). Palomares-Ríus et al. (2016) reported the existence of two QTL in LG5 associated with CYSDV resistance (cysdvq5.1 and cysdvq5.2) in TGR-1551.

The cotton-melon aphid, A. gossypii Glover, feeds on a wide range of dicotyledonous plants including members of the Cucurbitaceae family. In melon, this aphid species is considered an important pest being also an efficient vector of nonpersistent virus that seriously affects melon crops (Coudriet, 1962; Lecoq et al., 1979). In 1980, Pitrat and Lecoq found resistance to $A$. gossypii in the Korean melon line PI 161375 (Songwhan Charmi) controlled by the gene Vat. This gene belongs to the superfamily of the resistance genes ( $\mathrm{R}$ genes) (Dogimont et al., 2007) and it has been localized on LG5 in the sub-telomeric position (Périn et al., 2002), a region where several resistance genes homologous have been mapped. Dogimont et al. (2014) demonstrated that the Vat gene encodes for a CC-NBS-LRR protein that confers resistance to $A$. gossypii infestation and $A$. gossypii-mediated virus resistance. In 2004, Dogimont et al., had identified and used novel markers of the Vat and Vat-like genes. Among them, markers D and E allow the distinction of melon genotypes resistant/ susceptible to $A$. gossypii. The melon accession TGR-1551 has been described to be resistant to A. gossypii colonization (Vat gene) (Sarria-Villada et al., 2009, 2010; Soria et al., 2003).

Main melon market classes belong to cantalupensis and inodorus melon groups. One of the most popular types in inodorus group is Amarillo (Yellow Canary type) melons. These types of melons have ovate or round, with no ribs and no reticulated fruits, weighting around $2 \mathrm{~kg}$, of yellow skin that could be more or less wrinkled, without secondary color, usually without corking, although some fruits could be partially covered by very light longitudinal cork (writing), with small blossom scar, white or pale green flesh color, and sweet taste $\left(12-14^{\circ}\right.$ Brix). There are many commercial varieties/hybrids with fruits of these characteristics, but so far, only some of them carry intermediate resistance to powdery mildew, just a few of them carry the gen Vat and no one is resistant to CYSDV.

In this report, we describe the agronomic fruit traits and the behavior against $P$. xanthii, CYSDV, and $A$. gossypii of a new Yellow Canary breeding melon line, 'Carmen', derived through backcrossing from the cross between the line TGR-1551 (C. melo ssp. agrestis) and 'Bola de oro' (C. melo ssp. melo).

\section{Origin}

The melon line 'Carmen' was obtained by introgression of powdery mildew, CYSDV and $A$. gossypii resistances of TGR-1551 into the genetic background of the Spanish cultivar Bola de oro (Yellow Canary type). Five backcrosses (BC1, BC2, BC3, BC4, and $\mathrm{BC} 5$ ), followed by three self-pollinations (BC5S1, BC5S2, and $\mathrm{BC} 5 \mathrm{~S} 3$ ) have been carried out since 2009 to fix the resistances 
in the line. After each backcross, plants were assessed for CYSDV resistance based on symptomatology observed under natural conditions of infection; the selected plants, of similar behavior to F1 (TGR-1551 × 'Bola de oro') against CYSDV, were then used for the next backcross. No symptoms of powdery mildew were observed in most of the selected plants on each backcross generation. After the first self-pollination, a group of $50 \mathrm{BC} 5 \mathrm{~S} 1$ plants were analyzed not only for CYSDV resistance but also for the resistance to powdery mildew and presence of gene Vat. Both, the absence of powdery mildew symptoms in the field and the occurrence of the TGR-1551 genotype for the markers PM3CAPS and MRGH63 linked to $P$. xanthii races 1,2 , and 5 resistances were used to select powdery mildew resistant plants (Yuste-Lisbona et al., 2011a, 2011b). The markers D and E (Dogimont et al., 2004) were also used in these BC5S1 plants to identify the TGR-1551 alleles of the Vat gene. Plants were inoculated with the virus using $B$. tabaci as vector and following the methodology developed by Célix et al. (1996). Once the plants were inoculated were transferred to a greenhouse with graveled soil and drip irrigation. Eight weeks after their inoculation plants were evaluated for symptom severity and the third leaf from the plant apex of each plant was taken for RT-PCR analysis to estimate the presence of the virus, following the taqman assay described by GilSalas et al. (2007). Only those plants resistant to CYSDV and carrying the resistant genotype for the molecular markers linked to the powdery mildew resistance and for the Vat gene were used in a second self-pollination. The BC5S2 population was also evaluated for CYSDV resistance and genotyped to select plants resistant to powdery mildew and A. gossypi. BC5S2 plants selected for a third self-pollination were chosen not only for their resistances, but also for their fruit characteristics. The BC5S3 population obtained ('Carmen') together with its progenitors have been evaluated for resistances to the three pathogens described by both, bioassays and using molecular markers, and also phenotyped under greenhouse for some vegetative traits and fruit characters of commercial interest.

\section{Description and Performance}

All plants/genotype were evaluated for sex type (monoecious and andromonecious), leaf shape (entire or pentalobate in fully expanded leaf in the middle of the plant) and leaf color (light green, green, and dark green) and self-pollinated to set fruits. The fruit characters were evaluated at least in 10 fruits/genotype following the melon list of descriptors edited by IPGRI (2003): fruit shape (globular, elliptical, ovate), predominant skin color (yellow, orange), secondary skin color pattern (no secondary skin color, spotted), fruit surface (smooth, wrinkled), fruit netting (no netting, finely longitudinal netted, intermediate longitudinal netted), blossom scar size (small, intermediate, large), separation of peduncle from fruit (easy, difficult), skin hardness on fruit (intermediate, hard), main color of flesh (white, pale green), flesh texture (fibrous-dry, smooth-firm, grainy-firm), flesh flavor (insipid, intermediate, sweet), flesh acidity (low, slight, intermediate, high), fruit weight ( $\mathrm{kg}$ ), length (from the stem to blossom end in $\mathrm{cm}$ ) and diameter (at the broadest point, in $\mathrm{cm}$ ), flesh thickness (at maximum fruit diameter in $\mathrm{cm}$ ), ${ }^{\circ}$ Brix (using a PAL-1 digital refractometer, ATAGO Co, LTD, Tokyo, Japan), seed size (small, intermediate, large), predominant seed color (white, cream, light brown or tan), and 100 seed weight $(\mathrm{g})$. Vegetative, floral, and fruit characteristics of 'Carmen' are very close to commercial demands, similar to 'Bola de oro' (Table 1). Although most of the qualitative fruit traits were uniform, some of them showed some variability. Fruits of 'Bola de oro' exhibited a fine longitudinal netting but most of the plants of 'Carmen' yielded fruits with intermediate netting and even one to two fruits were covered by very fine and broad net. Fruits of TGR-1551 are absolutely smooth then, environmental conditions should have had a role in the expression of this character in the new breeding line (Fig. 1). Besides, the flesh texture was no as smooth as in 'Bola de oro' and the flesh acidity was a little higher than commercially desired in several fruits, although this character was measured only by a panel.

Table 1. Vegetative, floral, and fruit characters evaluated in TGR-1551, 'Bola de oro', and 'Carmen'.

\begin{tabular}{llll}
\hline Character & \multicolumn{1}{c}{ TGR-1551 } & \multicolumn{1}{c}{ 'Bola de oro' } & \multicolumn{1}{c}{ 'Carmen' } \\
\hline Sex type & Monoecious & Andromonoecious & Andromonoecious \\
Leaf shape & Entire & Pentalobate & Pentalobate \\
Leaf color & Dark green & Green & Green \\
Fruit shape & Eelliptical & Ovate & Ovate \\
Skin color & Orange & Yellow & Yellow \\
Secondary skin color & Spotted & No & No \\
Fruit surface & Smooth & Wrinkled & Wrinkled \\
Fruit netting & No & Finely longitudinal & Longitudinal \\
Blossom scar size & Small & Intermediate & Intermediate \\
Peduncle separation & Difficult & Difficult & Difficult \\
Main flesh color & White & White-pale green & White-pale green \\
Skin hardness & Hard & Intermediate & Intermediate \\
Flesh texture & Fibrous-dry & Smooth-firm & Smooth-firm \\
Flesh flavor & Insipide & Sweet & Sweet \\
Flesh acidity & High & Low & Slight \\
Fruit weight $(\mathrm{g})$ & $869.00 \pm 161.22$ & $1916.75 \pm 363.61$ & $1857.80 \pm 243.68$ \\
Fruit length $(\mathrm{cm})$ & $17.00 \pm 1.45$ & $18.90 \pm 1.48$ & $18.12 \pm 1.08$ \\
Fruit width $(\mathrm{cm})$ & $10.80 \pm 1.41$ & $13.05 \pm 1.03$ & $13.22 \pm 0.53$ \\
Flesh thickness $(\mathrm{cm})$ & $2.30 \pm 0.46$ & $3.53 \pm 0.34$ & $3.32 \pm 0.36$ \\
${ }^{\circ}$ Brix & $5.73 \pm 1.17$ & $13.90 \pm 0.64$ & $13.45 \pm 0.78$ \\
Seed size & Small & Intermediate & Intermediate \\
Seed color & Tan & White & White \\
100 seeds weight & $3.04 \pm 0.21$ & $5.60 \pm 1.02$ & $7.71 \pm 1.09$ \\
\hline
\end{tabular}
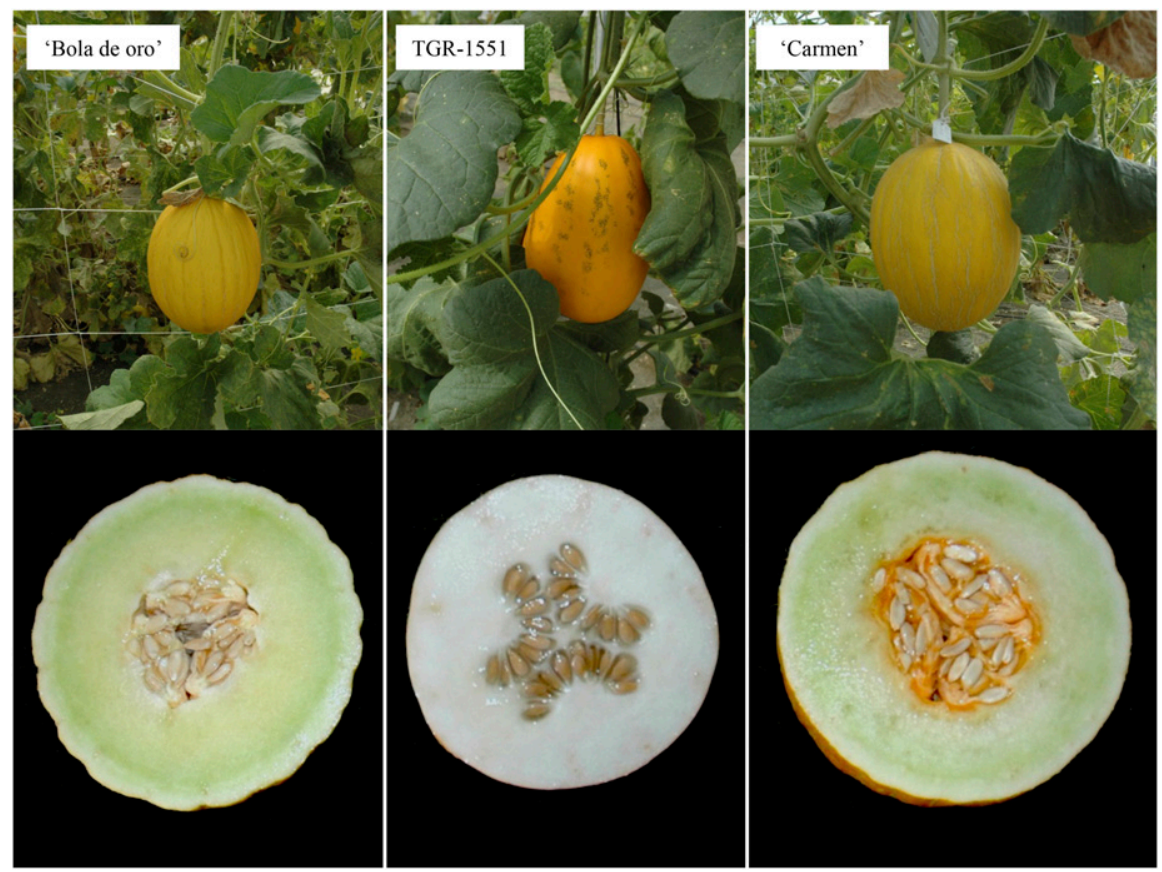

Fig. 1. Fruits of 'Bola de oro', TGR-1551, and 'Carmen'. 
However, fruits were juicy and with a content of soluble solids similar to fruits of 'Bola de oro' $\left(13.5^{\circ}\right.$ Brix $)$. Quantitative fruit traits in 'Carmen' fit the commercial values for this type of melons (Table 1).

Colonization resistance to $A$. gossypii tests were carried out following Pitrat and Lecoq (1980) and Sarria et al. (2008). All the experiments were carried out in a glasshouse, observing a temperature range of 21 to $36^{\circ} \mathrm{C}$ and a photoperiod of $\approx 16 \mathrm{~h} \mathrm{light} / 8 \mathrm{~h}$ dark. Forty-eight hours after deposition, the number of aphids remained on the infested leaf were recorded. All plants of 'Bola de oro', showed susceptibility to A. gossypii because more than four adults remained on the infested leaf $48 \mathrm{~h}$ after infestation. When plants of 'Carmen' and TGR-1551 were evaluated, the number of adults in that leaf ranged between 0 and 4 (mean values $\leq 2$ ), confirming that this new breeding line shows antixenosis against $A$. gossypii at the same level than TGR-1551 (Supplemental Fig. 1). Tolerance to $A$. gossypii was evaluated according to Ivanoff (1945) and $7 \mathrm{~d}$ after infestation with 10 apterous adults, plants of 'Bola de oro' showed leaf curling, but plants of TGR-1551 and 'Carmen' did not, which also indicates tolerance to $A$. gossypii in the new breeding line. Genotyping results of markers D and E linked to the Vat gene showed that the resistant allele in PI 161375 (control) and TGR-1551 and in all 'Carmen' individuals (samples 1-11), which demonstrated that 'Carmen' also carries the Vat gene; however, 'Bola de oro' showed the susceptible allele (Supplemental Fig. 2).

No bioassays were carried out for powdery mildew resistance. The behavior of plants under natural conditions of powdery mildew infection was recorded and PMR45, WMR29, Edisto 47, and PI 414723 plants allow us to identify the predominant race of $P$. xanthii in the greenhouse as race 5. No plants of 'Carmen' showed symptoms of powdery mildew under natural conditions of infection and they carried the resistant allele of the PM3 and MRGH63 markers associated with the dominant gene in LG5 of TGR-1551 (Supplemental Fig. 3). Regarding the recessive gene on LG12, none of the plants carried the TGR-1551 allele at the SNP61 locus (data not shown), therefore, indicating that the powdery mildew resistance found in 'Carmen' comes from the dominant gene located on LG5.

In addition, plants were inoculated two consecutive times with CYSDV using $B$. tabaci (Célix et al., 1996) with the clip-cage method (López-Sesé and Gómez-Guillamón, 2000). The two inoculations were spaced 2 weeks apart and then the plants were transferred to a plastic greenhouse. Presence of virus symptoms was visually assessed once a week over a 2-month period. The score was based on a visual scale of virus symptoms, ranging from $0=$ no symptoms to $5=$ almost the entire plant with clear symptoms. Symptom score at 8 weeks after inoculations was considered the phenotypic value of the line. At this time the third leaf from the plant apex of each plant was taken for RT-PCR analysis to estimate the presence of the virus in the plant. All plants of 'Bola de oro' showed clear symptoms of CYSDV (score 5) infection 3 weeks after the first inoculation and the presence of the virus in plants was confirmed by RT-PCR. However, no plants of 'Carmen' or TGR-1551 showed symptoms of yellowing incited by CYSDV (score 0 ), and no virus was detected at the end of the trial, 8 weeks after the first inoculation. Accordingly, the genotyping of 24 SNPs linked to the two major QTLs (cysdvq5.1 and cysdvq5.2) mapped in LG5 indicated that all plants of 'Carmen' were homozygous for TGR-1551 alleles in these genomic regions (data not shown).

Results of this study showed that even though CYSDV resistance was the only character used to select plants for backcrossing, the tight linkage existing among the three candidate regions/genes has resulted in a melon line that is highly resistant also to powdery mildew and A. gossypii. Thus, the new breeding line 'Carmen' fits the market requirements of the Yellow Canary type melons being resistant to two of the main melon diseases and one pest affecting this crop. Some nondesirable fruit traits derived from TGR-1551, such as extremely hard skin and other traits associated with the fruit flesh as texture, flavor, and acidity, has been removed in the breeding program. Despite a certain level of skin netting of the fruit and the slight acidity of the flesh, the characterization of fruits of the new breeding line supports the commercial value of the yellow type line 'Carmen'.

Taken together, the phenotyping and genotyping of the resistances have demonstrated that 'Carmen' has the genetic background that gives it a high potential to grow in areas where diseases incited by $P$. xanthii (races 1 , 2, and 5), A. gossypii, and CYSDV are a threat for melons. Hence, this line could be used as a tool for the introgression of these resistances to elite melon breeding lines.

\section{Availability}

Small samples of 'Carmen' seeds are available for research purposes and may be obtained by written request to the author (guillamon@eelm.csic.es).

\section{Literature Cited}

Beraldo-Hoischen, P., M.L. Gómez-Guillamón, and A.I. López-Sesé. 2012. QTL associated with one recessive gene for powdery mildew resistance in the melon genotype TGR-1551. Proc. Xth EUCARPIA Mtg. Genet. Breeding Cucurbitaceae. 498-503.

Célix, A., A.I. Lopez-Sesé, N. Almazara, M.L. Gómez-Guillamón, and E. Rodríguez-Cerezo. 1996. Characterization of Cucurbit yellow stunting disorder virus, a Bemisia tabaci transmitted closterovirus. Phytopathology 86:13701376.

Coudriet, D.L. 1962. Efficiency of various insects as vectors of Cucumber mosaic and Watermelon mosaic viruses in cantaloups. J. Econ. Entomol. 55:519-520.
Dogimont, C., A. Bendahmane, M. Pitrat, E. Burget-Bigeard, L. Hagen, A. Le Menn, J. Pauquet, P. Rouselle, M. Caboche, and V. Chovelon. 2004. New polynucleotide implicated in plant resistance, useful for producing transgenic plants resistant to Aphis gossypii and associated viral transmission, also encoded protein. World patent WO2004072109-A.

Dogimont, C., A. Bendahmane, M. Pitrat, E. BurgetBigeard, L. Hagen, A. Le Menn, J. Pauquet, P. Rouselle, M. Caboche, and V. Chovelon. 2007. Gene resistant to Aphis gossypii. US Patent. Application US 2007/0016977 A1.

Dogimont, C., V. Chovelon, J. Pauquet, A. Boualem, and A. Bendahmane. 2014. The Vat locus encodes for a CC-NBS-LRR protein that confers resistance to Aphis gossypii infestation and A. gossypii mediated virus resistance. Plant J. 80:993-1004.

Esteras, C., G. Formisano, C. Roig, A. Diaz, J. Blanca, J. Garcia-Mas, M.L. GómezGuillamón, A.I. López-Sesé, A. Lázaro, A.J. Monforte, and B. Picó. 2013. SNP genotyping in melons: Genetic variation, population structure, and linkage disequilibrium. Theor. Appl. Genet. 126:1285-1303.

Gil-Salas, F.M., J. Morris, A. Colyer, G. Budgeb, N. Boonhamb, I.M. Cuadrado, and D. Janssen. 2007. Development of real-time RT-PCR assays for the detection of Cucumber vein yellowing virus $(\mathrm{CVYV})$ and Cucurbit yellow stunting disorder virus (CYSDV) in the whitefly vector Bemisia tabaci. J. Virol. Methods 146:45-51.

IPGRI. 2003. Descriptors for Melon (Cucumis melo L.). International Plant Genetic Resources Institute, Rome, Italy.

Ivanoff, S.S. 1945. A seedling method for testing aphid resistance and its application to breeding and inheritance studies in cucurbits and other plants. J. Hered. 36:357-361.

Lecoq, H., S. Cohen, M. Pitrat, and G. Labonne. 1979. Resistance to Cucumber mosaic virus transmission by aphids in Cucumis melo. Phytopathology 69:1223-1225.

López-Sesé, A.I. and M.L. Gómez-Guillamón. 2000. Resistance to Cucurbit yellowing stunting disorder virus (CYSDV) in Cucumis melo L. HortScience 35:110-113.

McCreight, J.D. and W.M. Wintermantel. 2008. Potential new sources of genetic resistance in melon to Cucurbit yellow stunting disorder virus. Proc. IXth EUCARPIA Mtg. Genet. Breeding Cucurbitaceae. 173-179.

Palomares-Ríus, F.J., A. Garcés-Claver, and M.L. Gómez-Guillamón. 2016. Detection of two QTLS associated with resistance to cucurbit yellow stunting disorder virus in melon line TGR 1551. Proc. IXth EUCARPIA Mtg. Genet. Breeding Cucurbitaceae. 334-337.

Périn, C., S. Hagen, V. De Conto, N. Katzir, Y. Danin-Poleg, V. Portnoy, S. Baudracco-Arnas, J. Chadoeuf, C. Dogimont, and M. Pitrat. 2002. A reference map of Cucumis melo based on two recombinant inbred line populations. Theor. Appl. Genet. 104:1017-1034.

Pitrat, M. and H. Lecoq. 1980. Inheritance of resistance to Cucumber mosaic virus transmission by Aphis gossypii in Cucumis melo. Phtytopathology 70:958-961.

Sarria, E., F.J. Yuste-Lisbona, F.J. Palomares, A.I. López-Sesé, and M.L. Gómez-Guillamón. 2008. Inheritance of tolerance to Aphis gossypii in Cucumis melo TGR-1551 and its relation with resistance to virus transmission. Proc. IXth EUCARPIA Mtg. Genet. Breeding Cucurbitaceae. 459-463.

Sarria-Villada, E., E. Garzo, A.I. López-Sesé, A. Fereres, and M.L. Gómez-Guillamón. 2009. Hypersensitive response to Aphis gossypii 
Glover in melon genotypes carrying the Vat gene. J. Expt. Bot. 60:3269-3277.

Sarria-Villada, E., F.J. Palomares-Ríus, A.I. López Sesé, A. Heredia, and M.L. Gómez-Guillamón. 2010. Role of leaf glandular trichomes of melon plants in deterrence of Aphis gossypii Glover. Plant Biol. 12:503-511.

Shishkoff, N. 2000. The name of the cucurbit powdery mildew: Podosphaera (sect. Sphaerotheca) xanthii (Castag.) U. Braun \& N. Shish. comb. nov. (abstr.). Phytopathology 90:S133.

Sitterly, W.R. 1978. The powdery mildews of cucurbits, p. 359-379. In: D.M. Spencer (ed.).
The powdery mildew. Academic Press, London, UK.

Soria, C., E. Moriones, A. Fereres, E. Garzo, and M.L. Gómez-Guillamón. 2003. New source of resistance to mosaic virus transmission by Aphis gossypii in melon. Euphytica 133:313318.

Wisler, G.C., J.E. Duffus, H.Y. Liu, and R.H. Li 1998. Ecology and epidemiology of whiteflytransmitted closteroviruses. Plant Dis. 82:270280.

Yuste-Lisbona, F.J., C. Capel, M.L. GómezGuillamón, J. Capel, A.I. López-Sesé, and R. Lozano. 2011a. Codominant PCR-based markers and candidate genes for powdery mildew resistance in melon (C. melo L.). Theor. Appl. Genet. 122:747-758.

Yuste-Lisbona, F.J., C. Capel, E. Sarria, R. Torreblanca, M.L. Gómez-Guillamón, J. Capel, R. Lozano, and A.I. López-Sesé. 2011b. Genetic linkage map of melon ( $\mathrm{Cucu}$ mis melo L.) and localization of a major QTL for powdery mildew resistance. Mol. Breed. 27:181-192.

Yuste-Lisbona, F.J., A.I. López-Sesé, and M.L. Gómez-Guillamón. 2009. Inheritance of resistance to races 1, 2 and 5 of powdery mildew in the melon TGR-1551. Plant Breed. 129:72-75. 


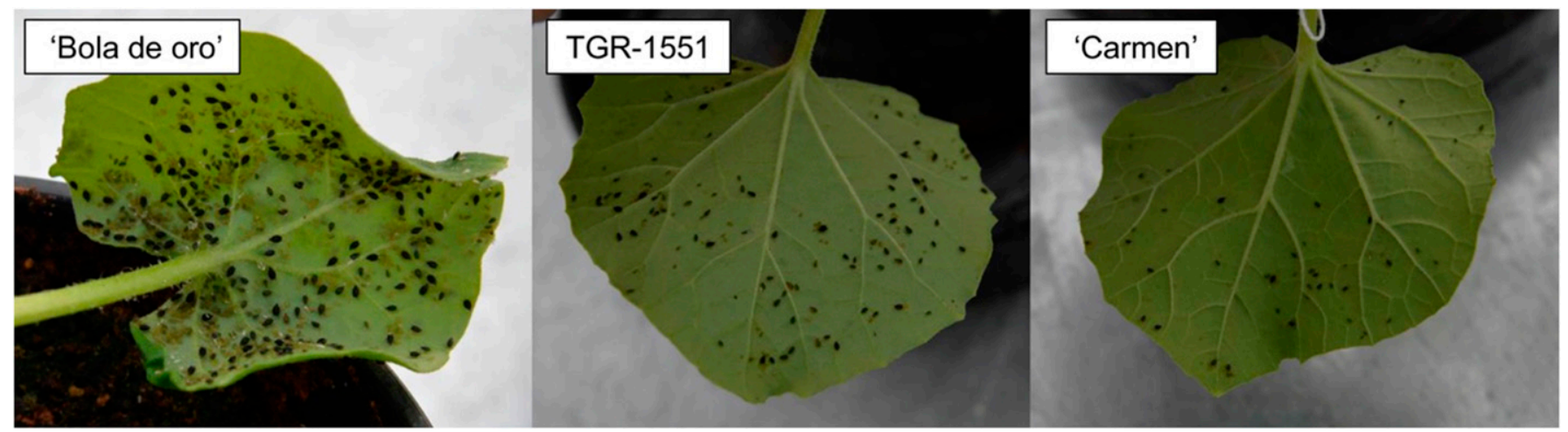

Supplemental Fig. 1. Adults and nymphae of Aphis gossypii on abaxial leaf layers of plants of 'Bola de oro', TGR-1551, and 'Carmen' $7 \mathrm{~d}$ after their infestation with 10 apterous adults of this aphid species.

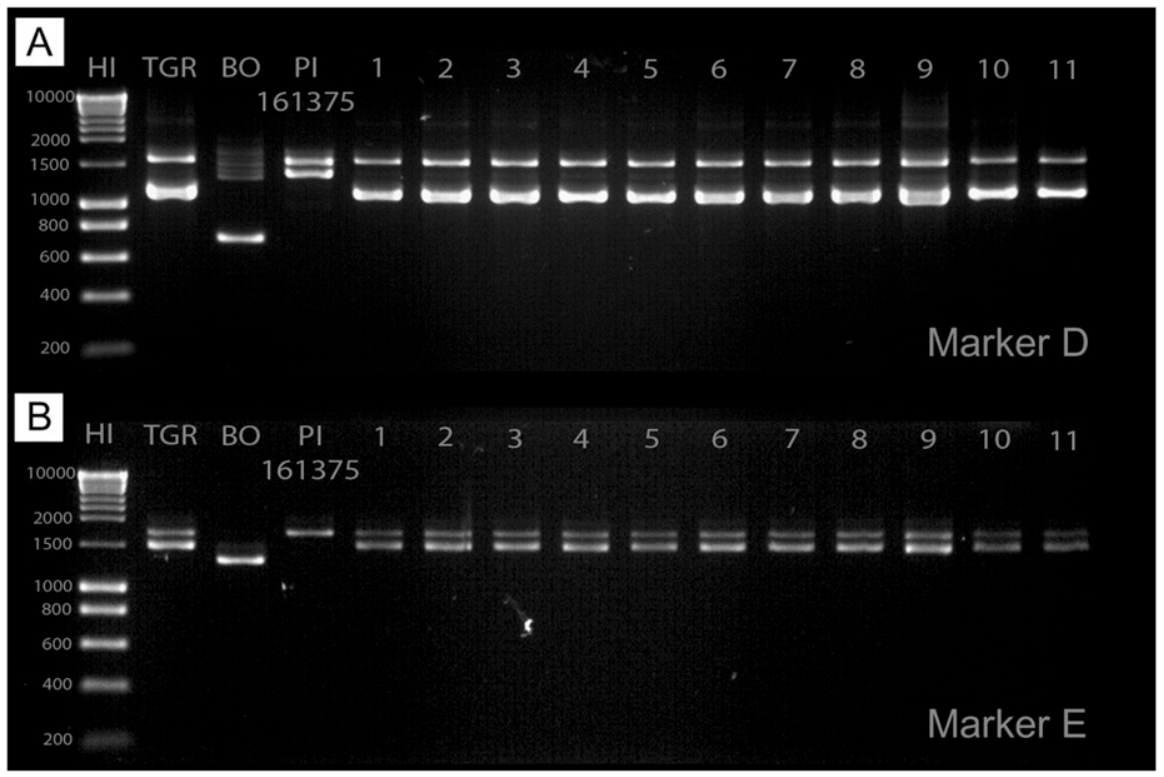

Supplemental Fig. 2. Genotyping results of markers D and E linked to the Vat gene that promotes resistance to Aphis gossypii.

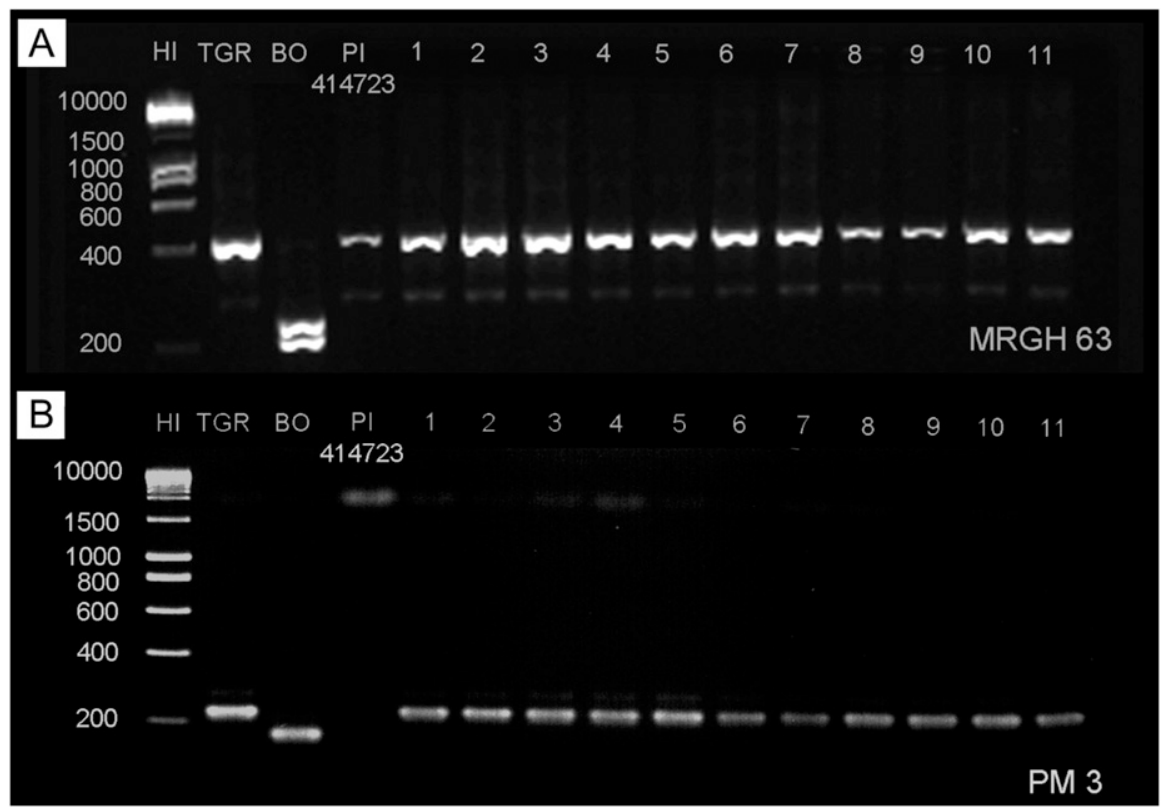

Supplemental Fig. 3. Genotyping results of the markers MRGH63 and PMR3. 